\title{
PENGEMBANGAN SENTRA PERTANIAN PERKOTAAN (URBAN FARMING) MENGGUNAKAN STRUKTUR AIR INFLATED GREENHOUSE
}

\author{
M. Ikhsan Setiawan ${ }^{1}$, Hery Budiyanto ${ }^{2}$, Koespiadi $^{3}$ \\ ${ }^{I}$ M. Ikhsan Setiawan, Universitas Narotama, ikhsan.setiawan@narotama.ac.id \\ ${ }^{2}$ Hery Budiyanto, Universitas Merdeka Malang, budiyantohery@yahoo.com \\ ${ }^{3}$ Koespiadi, Universitas Narotama, koespiadi@narotama.ac.id
}

\begin{abstract}
ABSTRAK
Pertanian Perkotaan (Urban Farming) adalah bertani dengan memanfaatkan lahan sempit atau intensifikasi lahan, guna memenuhi kebutuhan sayuran dan buah segar sehari-hari bagi masyarakat pemukiman/perumahan di perkotaan. Teknologi Air Inflated Structure sebagai fasilitas pendukung peningkatan produksi Pertanian Perkotaan, dengan sistem portabel Greenhouse dapat dibangun serta dipindahkan ke lokasi tertentu secara mudah, aman, cepat, bahan struktur ringan $(0,55 \mathrm{~mm}$ PVC Terpaulin) sehingga produk Pertanian Perkotaan semakin dekat dengan konsumen pemukiman di Perkotaan, dampaknya harga semakin murah namun berkualitas. Tujuan Penelitian adalah merencanakan, membuat dan menguji protitipe tenda Air Inflated Structure sebagai fasilitas Urban Farming guna memenuhi aspek kekuatan, kecepatan, efektifitas dan kenyamanan Greenhouse. Metode Penelitian menggunakan Metode Eksperimen, diawali dengan perancangan, pembuatan dan pengujian prototipe tenda meliputi (1) uji kekuatan dan ketahanan bahan terhadap cuaca (2) uji meterial yang paling efektif guna komponen struktur (3) uji kecepatan pembuatan, pengangkutan, perakitan, pemasangan, pembongkaran (4) uji kenyamanan. Pengujian dilakukan di Lab Universitas Narotama dan Lab Universitas Merdeka Malang, terbukti memberikan hasil yang handal dan memuaskan meliputi kuat uji tarik hingga $218,3 \mathrm{~kg}$, daya tahan bahan hingga $>70^{\circ} \mathrm{C}$, kecepatan instalasi pemasangan dan pembongkaran menjadi lebih efektif dan efisien serta kenyamanan dalam ruangan suhu maksimum $35^{\circ} \mathrm{C}$.
\end{abstract}

Kata Kunci : Air Inflated Structure, Urban Farming, Greenhouse

1. PENDAHULUAN

FAO (Food and Agriculture Organization) menjelaskan Pertanian Perkotaan sebagai industri yang memproduksi, memproses, dan memasarkan produk pertanian, terutama memenuhi permintaan harian konsumen di dalam perkotaan, dengan metode produksi intensif, memanfaatkan dan mendaur ulang sumber daya dan limbah perkotaan untuk menghasilkan beragam tanaman kebutuhan pangan masyarakat Perkotaan (Smit, J, A. Ratta, J. Nasr, 1996). Council on Agriculture, Science and Technology (CAST) menyatakan Pertanian Perkotaan mencakup aspek kesehatan lingkungan, remediasi, dan rekreasi (Butler, L, Moronek, D.M, 2002). Di berbagai kota, Pertanian Perkotaan menjadi pendukung aspek keindahan kota dan kelayakan penggunaan tata ruang yang berkelanjutan. Pertanian Perkotaan juga dilakukan untuk meningkatkan pendapatan atau aktivitas memproduksi bahan pangan untuk dikonsumsi keluarga, dan di beberapa tempat dilakukan untuk tujuan rekreasi dan relaksasi (Fraser, Evan D.G, 2002). Pertanian Perkotaan memberikan hasil yang optimal dengan fasilitas Greenhouse dan teknologi Hidroponik. Greenhouse meningkatkan perlindungan tanaman dari intensitas 
hujan, sinar matahari dan iklim mikro, serta mengoptimalkan pemeliharaan tanaman, pemupukan dan irigasi mikro, sehingga mampu meningkatkan produksi sayuran, buah dan bunga yang berkualitas tanpa tergantung dengan musim (G. Thiyagarajan, R. Umadevi \& K. Ramesh, 2007). Greenhouse semakin mudah dengan teknologi Air Inflated Structure yang dapat memenuhi syarat kekuatan, kenyamanan dalam ruang dan kecepatan dalam pembangunan Greenhouse tersebut. Bahan membran Air Inflated Structure dapat tahan terhadap cuaca hingga lebih dari 10 tahun, bergantung kepada jenis bahan coatingnya (Ikhsan, $M$, 2014).

Terdapat 5 aspek utama yang menjadi masalah dalam penelitian ini, yaitu:

a. Perancangan dan desain air inflated structure.

b. Pembuatan prototipe bangunan air inflated structure dilanjutkan uji material bangunan

c. Kecepatan dan efektivitas dalam proses pengangkutan, perakitan, pemasangan serta pembongkaran bangunan air inflated structure.

d. Tingkat kenyamanan termal dalam bangunan air inflated structure.

Berdasarkan latar belakang dan identifikasi masalah, maka dapat dirumuskan masalahmasalah sebagai berikut

a. Bagaimana perancangan dan desain air inflated structure?

b. Bagaimana pembuatan prototipe air inflated structure dilanjutkan uji material bangunan?

c. Bagaimana kecepatan dan efektivitas dalam proses pengangkutan, perakitan, pemasangan serta pembongkaran air inflated structure?

d. Bagaimana tingkat kenyamanan termal dalam air inflated structure?

Penelitian ini difokuskan pada beberapa kajian sebagai berikut:

a. Perancangan serta pembuatan sistem dan komponen bangunan air inflated structure

b. Pembuatan prototipe air inflated structure

c. Uji laboratorium bangunan air inflated structure

d. Peningkatkan kecepatan dan efektivitas dalam pembuatan, pengangkutan, perakitan, pemasangan serta pembongkaran bangunan air inflated structure

e. Peningkatkan kenyamanan termal bangunan air inflated structure
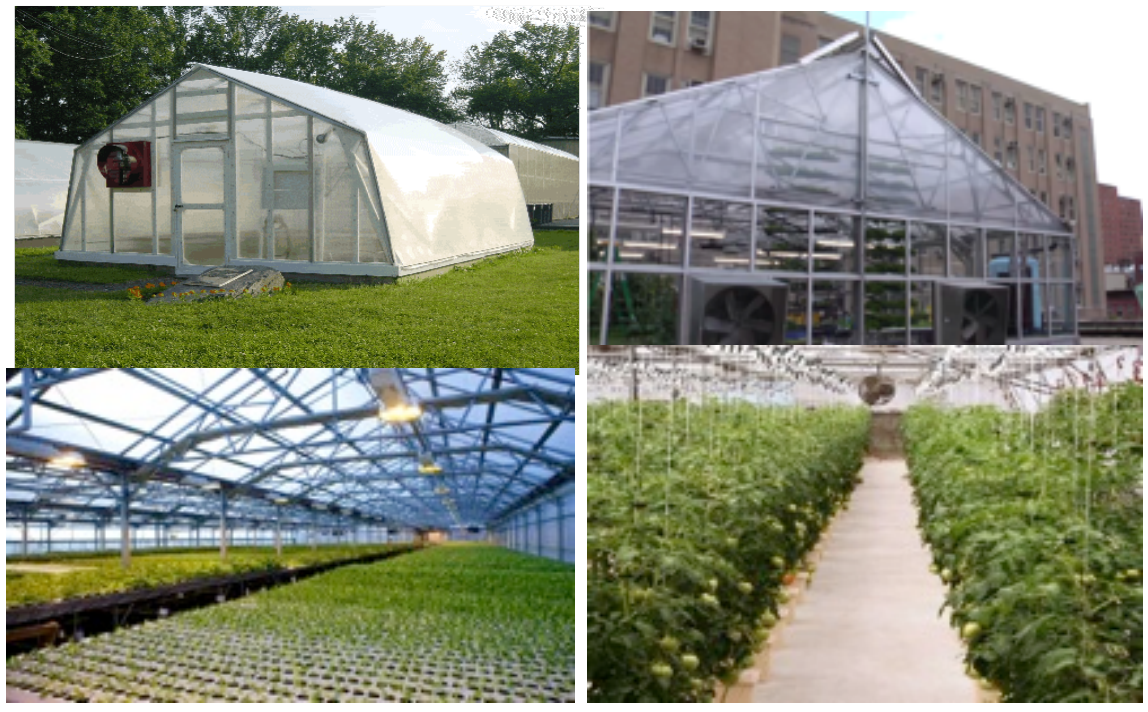

Gambar 1. Greenhouse dan alat pendukungnya

Sumber: greenestcity.ca 


\section{METODE PENELITIAN}

Penelitian ini menggunakan metode eksperimental berupa pembuatan prototipe struktur, melakukan aplikasi uji coba terhadap berbagai variabel, antara lain pengujian pengaruh bahan membran terhadap berbagai kondisi cuaca (variabel kekuatan bahan struktur terhadap sinar matahari, dan hujan), pengujian terhadap variabel berbagai jenis sambungan dan variabel kenyamanan termal bagi orang yang menempatinya. Pelaksanaan penelitian diawali dengan kajian literatur kemudian pembuatan desain (bentuk struktur, pola dasar lembaran membran, komponen dan elemen struktur) yang dilaksanakan di Lab. Komputer, dilanjutkan perancangan dan pembuatan prototipe struktur dengan skala dengan pilihan bahan dan sistem sambungan yang paling efisien. Prototipe ini diuji (selama 1 bulan) terutama aspek kenyamanan

Penelitian dan pengujian terhadap sistem struktur pneumatik, antara lain dalam uji model struktur pneumatik pada tahun 1992 telah dilakukan dalam paper "Kajian dan Perancangan Bangunan dengan Konsep Struktur Pneumatik yang Ditekankan pada Aspek Teknik dan Metoda Konstruksi, Kasus Studi: Struktur Atap Pneumatik Membran Tunggal yang Ditumpu Udara pada Gedung Olah Raga" (Budiyanto, 1992). Eksperimen model struktur diperlukan untuk mengetahui perilaku struktur sesungguhnya (prototipe) dengan menggunakan replika (model) struktur yang skalanya lebih kecil. Salah satu rekomendasi penelitian tersebut adalah struktur pneumatik memiliki beberapa kelebihan dibandingkan dengan struktur bangunan konvensional, yaitu investasi awal lebih murah, kecepatan dan kemudahan pembangunan, pemeliharaan mudah, elemen struktur dapat dilipat (ringkas) sehingga dapat disimpan dalam gudang dengan ukuran $3 \times 3 \mathrm{~m} 2$. Eksperimen dilanjutkan dengan Penelitian Hibah Bersaing DIKTI Tahun 2008-2010 yang menghasilkan prototipe struktur pneumatik yang ditumpu oleh udara. Prototipe ini dapat dibangun hanya dalam waktu 30 menit, bangunan seluas $150 \mathrm{~m} 2$ siap menampung 50 orang. Kelemahan dari prototipe ini adalah penggunaan pintu rigid yang harus kedap udara sehingga menyulitkan penduduk yang relative awam untuk membiasakan diri keluar masuk dari tenda gelembung. Hasil riset Purwanto yang dituangkan dalam tulisan berjudul "Perkembangan Struktur Pneumatik Memperkaya Desain Arsitektur" (Purwanto, 2000) menyampaikan kemungkinan penerapan dan pengembangan struktur pneumatic di Indonesia, antara lain kondisi iklim di Indonesia, terutama masalah angin, bukanlah masalah yang berarti dan dapat diperhitungkan dengan perhitungan tekanan dalam struktur pneumatik. Hal-hal yang perlu dipertimbangkan dalam penggunaan struktur pneumatik di Indonesia, antara lain perilaku, kondisi sosial masyarakat Indonesia perlu ditingkatkan terutama dalam pemeliharaan bangunan. Aspek keisengan masyarakat dalam memandang dan memperlakukan bangunan/fasilitas umum sering menimbulkan kerusakan. Namun, masyarakat perlu dibiasakan dan dikenalkan dengan sistem struktur baru ini sehingga dapat belajar pada satu kondisi, bentuk, perilaku atau peradaban baru. Alain Chassagnoux dan kawan-kawan dalam "Teaching of Morphology" (Chassagnoux et.al., 2002) menjelaskan bahwa untuk mempelajari bentuk-bentuk arsitektur kontemporer yang menggunakan struktur non-konvensional. Para dosen bisa mengajak mahasiswa untuk melakukan eksperimen model sehingga mendapatkan pengalaman "membentuk" bangunan menggunakan elemen/komponen yang dirancang sendiri oleh mahasiswa. Dengan studi bentuk bangunan melalui studi geometri dan sains akan memberikan pengalaman pembentukan struktur bangunan yang sulit dilakukan dan hiperhitungkan secara matematis.

Pertanian Perkotaan memunculkan komunitas seperti "foodies", "locavores", "organic growers" yang berfungsi sebagai sarana berbagi informasi dan fasilitas jual beli produk 
setempat, sehingga mendatangkan penghasilan, mengurangi risiko pestisida dan bahan kimia berlebih dalam konsumsi masyarakat, sehingga meningkatkan ketahanan pangan, karena mendekatkan jarak antara produsen dan konsumen sehingga bahan pengawet dan proses tambahan tidak dibutuhkan. Hal ini membuat konsumen mendapatkan jaminan bahan pangan yang didapatkan begitu segar (Thornton, A, 2011). Studi memperlihatkan bahwa dengan berpindah dari bahan pangan yang ditumbuhkan secara lokal dapat menghemat emisi dari transportasi bahan makanan sebanyak 50.000 metrik ton karbon dioksida, yang setara dengan menghilangkan 16.191 mobil dari jalan. Sebagai dampak berkurangnya penggunaan energi, jejak karbon dari suatu kota akibat usaha Pertanian Perkotaan juga berkurang. (Xuereb, M, 2005), (Delta Institute, 2013). Teknologi Air Inflated Structure Greenhouse dalam Pertanian Perkotaan memenuhi syarat kekuatan, kenyamanan dalam ruang dan kecepatan dalam pembangunannya, bahan membran Air Inflated Structure dapat tahan terhadap cuaca hingga lebih dari 10 tahun, bergantung kepada jenis bahan coatingnya (Ikhsan, M, 2014).

Tabel 1. Variabel Dan Uji Penelitian

\begin{tabular}{|c|c|c|}
\hline Variabel & Cara Pengujian & Alat Uji \\
\hline $\begin{array}{l}\text { a. Kekuatan dan } \\
\text { ketahanan bahan } \\
\text { membran struktur }\end{array}$ & $\begin{array}{l}\text { Pemilihan jenis bahan membran } \\
\text { yang paling kuat dan tahan } \\
\text { - uji kekuatan bahan } \\
\text { - uji ketahanan terhadap cuaca }\end{array}$ & $\begin{array}{l}\text { Uji tarik }>100 \mathrm{~kg} \\
\text { Uji bakar }>70 \%\end{array}$ \\
\hline $\begin{array}{l}\text { b. Efisiensi Sistem } \\
\text { dan Komponen } \\
\text { Struktur }\end{array}$ & $\begin{array}{l}\text { Pemilihan terhadap berbagai } \\
\text { katagori untuk mendapatkan yang } \\
\text { paling efektif. } \\
\text { - Komponen struktur } \\
\text { - Jenis sambungan }\end{array}$ & $\begin{array}{l}\text { Kualitatif: } \\
\text { Memperhatikan } \\
\text { kemudahan dan } \\
\text { efisiensi dalam } \\
\text { membuat dan } \\
\text { memasang }\end{array}$ \\
\hline $\begin{array}{l}\text { c. Kecepatan proses } \\
\text { pengangkutan, } \\
\text { perakitan, } \\
\text { pemasangan, } \\
\text { pembongkaran }\end{array}$ & $\begin{array}{l}\text { - Waktu dan sistem pembuatan } \\
\text { - Waktu dan sistem pengangkutan } \\
\text { - Waktu dan sistem perakitan } \\
\text { - Waktu dan sistem pemasangan } \\
\text { - Waktu dan sistem pembongkaran }\end{array}$ & Stopwatch \\
\hline $\begin{array}{l}\text { d. Kondisi termal } \\
\text { bangunan dan } \\
\text { kenyamanan termal } \\
\text { pengguna bangunan }\end{array}$ & $\begin{array}{l}\text { Meneliti kondisi bangunan tenda } \\
\text { sebelum dan selama dihuni: suhu } \\
\text { dan kelembaban di dalam dan } \\
\text { luar bangunan } \\
\text { - Meneliti aspek kenyamanan } \\
\text { termal penghuni selama berada } \\
\text { di dalam bangunan }\end{array}$ & Termometer \\
\hline
\end{tabular}


Tabel 2: Tahapan, Luaran, dan Indikator Capaian Penelitian

\begin{tabular}{|c|l|l|l|}
\hline Tahapan & \multicolumn{1}{|c|}{ Penelitian } & \multicolumn{1}{c|}{ Luaran } & \multicolumn{1}{|c|}{ Indikator Capaian } \\
\hline 2013 & $\begin{array}{l}\text { Perancangan dan } \\
\text { Pembuatan Air Inflated } \\
\text { Structure }\end{array}$ & $\begin{array}{l}\text { Prototipe } \text { Air } \\
\text { Inflated Structure }\end{array}$ & $\begin{array}{l}\text { Inflated Structure telah } \\
\text { dirancang dan dibuat di } \\
\text { Lab Universitas } \\
\text { Narotama }\end{array}$ \\
\hline 2014 & $\begin{array}{l}\text { Pengujian Air Inflated } \\
\text { Structure }\end{array}$ & $\begin{array}{l}\text { Prototipe Air } \\
\text { Inflated Structure }\end{array}$ & $\begin{array}{l}\text { 1 unit Prototipe Air } \\
\text { Inflated Structure telah } \\
\text { diuji di Lab } \\
\text { Universitas Merdeka } \\
\text { Malang }\end{array}$ \\
\hline
\end{tabular}

\section{HASIL PENELITIAN}

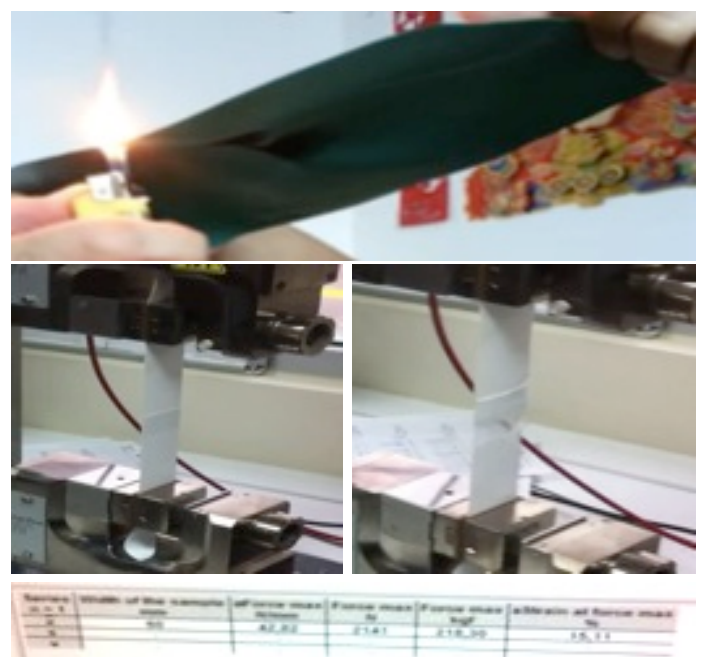

Gambar 2. Uji Panas dan Uji Tarik terhadap Material Air Inflated Structure di Lab

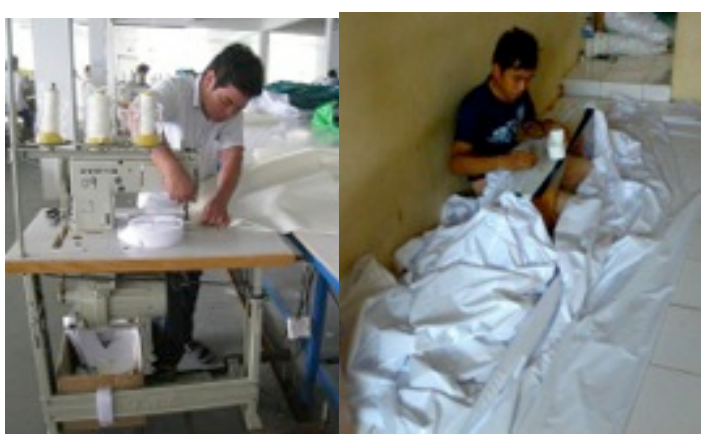

Gambar 3. Pabrikasi Tenda 21 Hari 


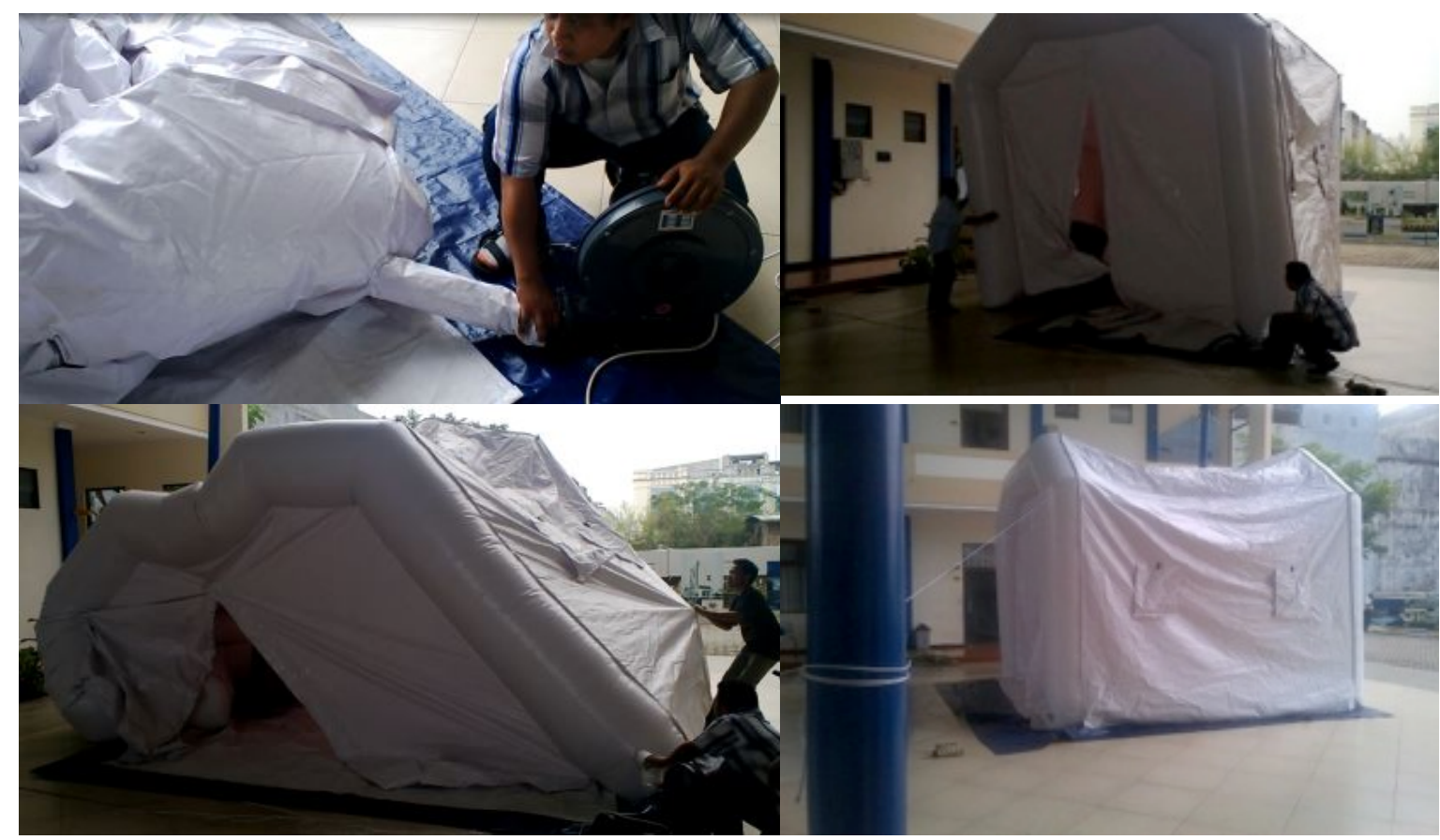

Gambar 4. Instalasi 3menit \& Pemasangan 3menit

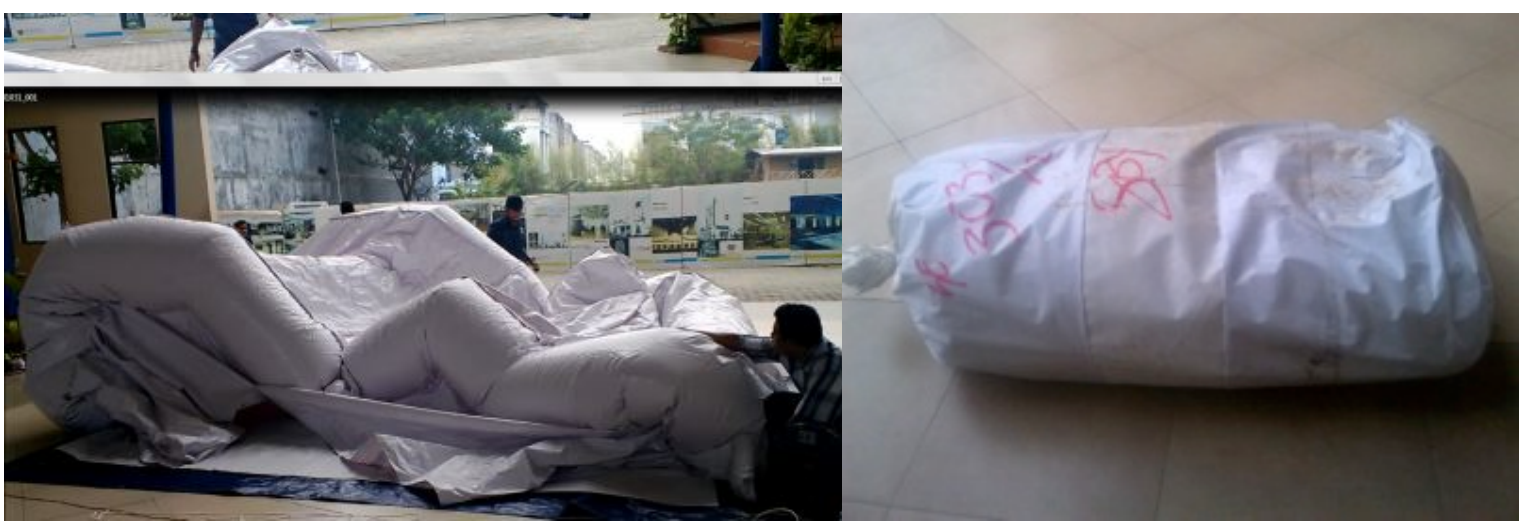

Gambar 5. Bongkar 3menit \& Packing 3menit

40

30

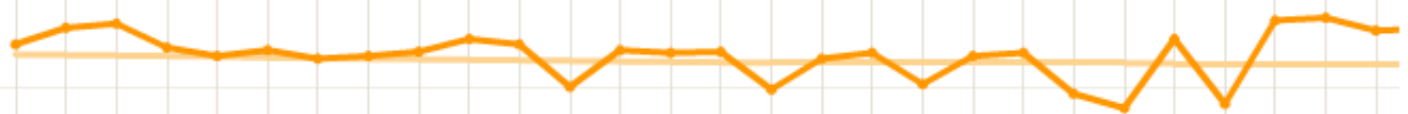

20

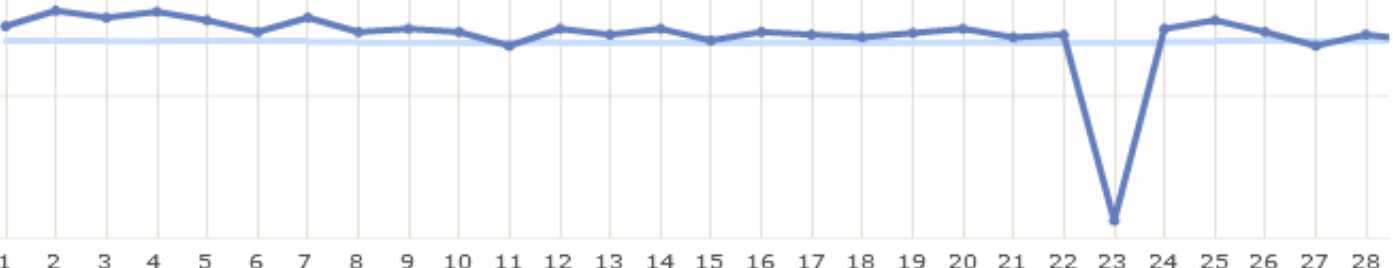

Gambar 6. Grafik Suhu Ruangan Air Inflated Structure Desember 2013

Pengujian di Lab Teknik Sipil Univ Narotama Surabaya 


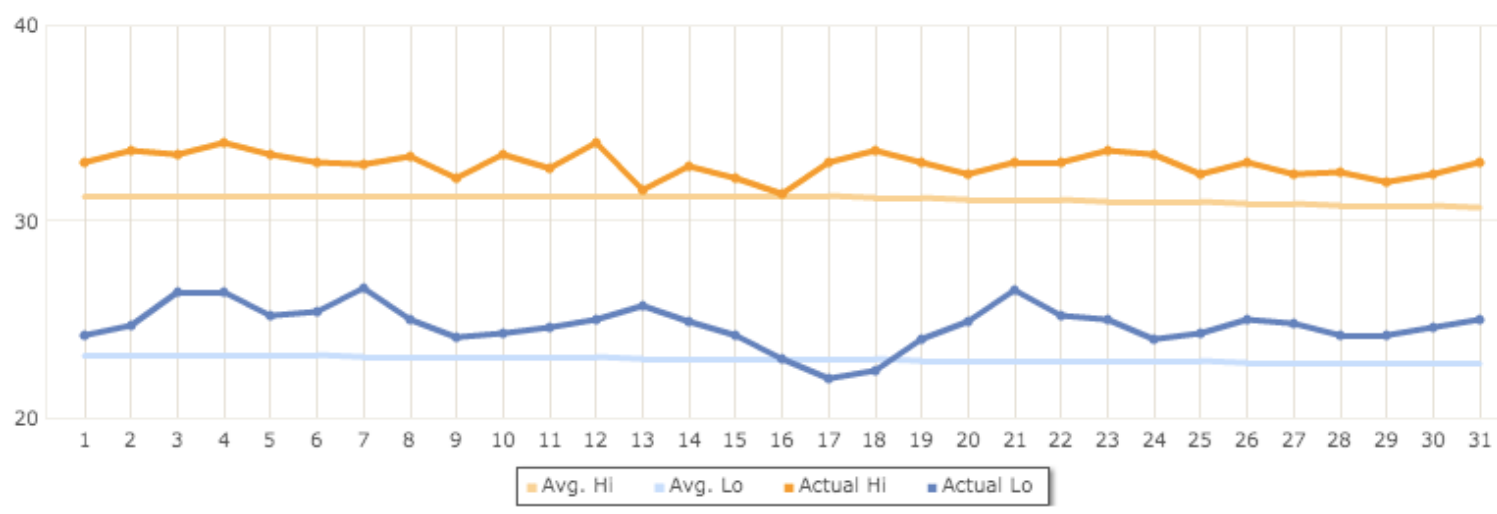

Gambar 7. Grafik Suhu Ruangan Air Inflated Structure Juli 2014 Pengujian di Lab Bahan Univ Merdeka Malang

\section{KESIMPULAN}

Bangunan Air Inflated Structure sebagai Greenhouse untuk fungsi Urban Farming sangat sesuai, disebabkan kecepatan, kemudahan dan kenyamanan bangunan struktur tersebut. Terbukti dalam Uji Laboratorium dan Uji Lapangan didapatkan hasil yang handal meliputi kuat uji tarik hingga $218,3 \mathrm{~kg}$, daya tahan material $>70^{\circ} \mathrm{C}$, instalasi 3 menit, pemasangan 3 menit dan pembongkaran 3menit serta suhu dalam ruangan $<35^{\circ} \mathrm{C}$. Bangunan Air Inflated Structure dapat menjadi prototipe nasional sebagai Greenhouse Urban Farming. Penggunaan bahan tarpaulin dan PVC sangat fleksibel dan kuat sehingga memudahkan proses pengangkutan, pemasangan dan pembongkaran kembali, dalam packaging yang simpel dan mudah digunakan. Namun penggunaan bahan tarpaulin dan PVC pada bangunan air inflated structure memerlukan informasi atau sign agar terhindar dari bahaya kebocoran dan kebakaran akibat barang-barang yang mudah terbakar, kegiatan merokok maupun mengelas didekat area tenda

\section{DAFTAR PUSTAKA}

1. Budiyanto, Hery (1992) Kajian dan Perancangan Bangunan dengan Konsep Struktur Pneumatik yang Ditekankan pada Aspek Teknik dan Metoda Konstruksi, Kasus Studi: Struktur Atap Pneumatik Membran Tunggal yang Ditumpu Udara pada Gedung Olah Raga, Tesis S2, Institut Teknologi Bandung

2. Budiyanto, Hery (2007) Ujicoba Model Dan Prototipe Tenda Pneumatik Sistem Knock Down Sebagai Bangunan Penampungan Sementara Untuk Korban Bencana, Laporan Penelitian Hibah Kompetisi A2, Teknik Arsitektur Universitas Merdeka Malang

3. Budiyanto, Hery (2010) Pembuatan Tenda Pneumatik Sistem Knock Down Yang Ringkas Dan Cepat Bangun Sebagai Bangunan Penampungan Sementara Untuk Korban Bencana, Laporan Penelitian Hibah Bersaing Tahun 2008-2010, Teknik Arsitektur Universitas Merdeka Malang

4. Butler, L, Moronek, D.M (2002) Urban and Agriculture Communities: Opportunities for Common Ground, Ames, Iowa: Council for Agricultural Science and Technology 
5. Chassagnoux, Alain, et.al (2002) Teaching of Morphology, International Journal of Space Structures, Vol.17 No. 2 \& 3, Multi Science Publishing Ltd., Brendwood (UK)

6. Delta Institute, Urban Agriculture

7. Dent, Roger N (1971) Principles of Pneumatic Architecture. London: Elsevier Publishing Company

8. Fraser, Evan, D.G (2002) Urban Ecology in Bangkok Thailand: Community Participation, Urban Agriculture and Forestry, Environments 30 (1).

9. G. Thiyagarajan, R. Umadevi \& K. Ramesh (2007) Hydroponics, Science Tech Entrepreneur-Water Technology Centre-Tamil Nadu Agricultural University, India

10. Herzog, Thomas (1976) Pneumatic Structures, a handbook for the architect and engineer. London: Crosby Lockwood Staples

11. Ikhsan, M (2014) The Development of Air Inflated Structure as the Facility on Natural Disaster Area, Australian Journal of Basic and Applied Sciences, ISSN 1991-8178, April Issue 2014

12. Intent (2005) Membran Structures. Kortrijk: Intent Inc

13. Itek (2005) Air Cell Technology. Pennsylvania: Inflatable Technology-USA Inc

14. Luchsinger, Rolf H. et.al. (2004) Pressure Indicated Stability: From Pneumatic Structure to Tensairity. Article No.JBE-2004-025, Journal of Bionic Engineering. Vol.1. No.3, hal.141-148, Jilin University - Nanling Campus, Changchun PR China

15. Otto, Frei (1973) Tensile Structures. Cambridge: The MIT Press

16. Purwanto (2000) Perkembangan Struktur Pneumatik Memperkaya Desain Arsitektur. Jurnal Dimensi Vol 28 No. 1, Universitas Kristen Petra, Surabaya

17. Salvadori, Mario (1981) Structural Design in Architecture. New Jersey: Prentice Hall Inc

18. Schodek, Daniel (1980) Structures. New Jersey: Prentice Hall. Inc

19. Schueller, Wolfgang (1983) Horizontal Span Building Structures. New York : John Wiley \& Sons

20. Smit, J., A. Ratta, J. Nasr (1996) Urban Agriculture: Food, Jobs, and Sustainable Cities. United Nations Development Programme (UNDP), New York, NY.

21. Sukawi (2011) Struktur Membran dalam Bangunan Bentang Lebar, Jurnal Modul Vol.11 No.1. ISSN:0853-2877, Universitas Diponegoro, Semarang

22. Thornton, A (2011) Food for thought? The potential of urban agriculture in local food production for food security in the South Pacific. In Campbell, H. Rosin, C. and Stock, P. (eds) Dimensions of the Global Food Crisis. London: Earthscan. Pg 200-218.

23. Xuereb, Marc (2005) Food Miles: Environmental Implications of Food Imports to Waterloo Region. Public Health Planner Region of Waterloo Public Health

24. Zuhri, Syaifudin (2010) Dasar-dasar Tektonik: Arsitektur dan Struktur. Klaten: Yayasan Humaniora 